\title{
The Availability of Facilities and Infrastructure and the Quality Assurance of Education at MTs Darul Huda Mataraman During the Covid-19 Pandemic
}

\author{
Nadia Hardini Puteri*, Sugiyono
}

\author{
Universitas Negeri Yogyakarta, Indonesia \\ *Corresponding author. Email: nadiadinitri@gmail.com
}

\begin{abstract}
This paper analyzed the availability of facilities and infrastructure to support the implementation of online learning and the quality of education at MTs Darul Huda Mataraman. The researcher was qualitative descriptive research conducted at MTs Darul Huda Mataraman. The data were collected through observation, interviews, documentation, and data analysis techniques, namely reduction of the data, presentation of the data, and conclusions. The results indicated that the facilities and infrastructure support the implementation of online learning during the Covid-19 period and school quality. The results also showed factors that need improvement or development in the online learning process. It is recommended to improve the quality of education at MTs Darul Huda Mataraman to achieve the quality of online teaching and learning during the Covid-19 pandemic.
\end{abstract}

Keywords: infrastructure, learning in the time of covid-19, quality of education

\section{INTRODUCTION}

Education is a key to the progress of a nation. Furthermore, education has a very strategic role in determining the nation's future direction future and the quality of public knowledge. The purpose of education is to direct the growth and development of students' potential to become devoted to God Almighty and have noble characters. Learning activities in schools are the main activities in improving the quality of national education. Through the teaching and learning process, it is hoped that educational goals can be achieved by improving students' behavior [1].

In achieving a goal desired by the school, the organization's role becomes essential. Leaderships are considered to play a role in setting vision and goals to improve students' learning. This impact is mainly felt through the capacity of principals to support teachers in experimenting with ideas related to the school's vision [2]. The quality of education is one of the critical issues today. The task of involving the entire team in the educational organization is challenging. This is closely related to the task of creating the core value of the organization in general [3].

School-level barriers to online learning are mostly related to hardware and software availability, access to internet connections, and school policies. The teacher also reported a lack of time to prepare lesson textbooks and technical support as the main obstacles. Curriculum barriers include discrepancies between student assessments and e-learning. Another problem is that the curriculum may not support technology-based applications. Student level barriers include inadequate student e-learning skills, lack of student access to technology infrastructure and internet connections, and lack of motivation to use e-learning [4]. Covid-19 has impacted conventional learning methods used by academic institutions around the world. In terms of school administrations, colleges and universities choose online courses/classes as an alternative way to continue their education [5].

The COVID-19 pandemic was an unplanned and unprecedented event that changed the work of teachers in many aspects [6]. The impact of globalization on 
culture and the education system is a significant concern because globalization is a phenomenon that has an overall effect. Education is at the heart of the changes that dramatically affect our world in science, technology, economics, and culture. Technological capabilities are significant in this 4.0 era because countries need communication infrastructure and production systems to process and use the information for developers to place education. Equitable education is the primary step that the government must implement. One of which is to improve learning facilities and school opportunities for communities in remote areas [7].

Indonesia is a country with a high population, but the quality of education still requires a lot of improvements. A school itself does not guarantee a promising future. Educators should foster the ability of students to think, manage and capture new knowledge and information that can be useful for their lives. In the learning objectives themselves, many essential points in life need to be explored in the learning process. They will undoubtedly increase knowledge and all information in the learning activities themselves and even be able to positively influence the development of individual abilities that do not forget the learning process and goals.

The purpose of this research was to provide an overview of various supporting factors for the online learning process, mainly related to the available facilities and infrastructure, and to evaluate the quality of education in the MTs Darul Huda Mataraman.

\section{METHODS}

The data sources used primary and secondary data based on qualitative descriptive research. The sampling technique was purposive sampling, while the research location was in the MTs Darul Huda Mataraman. The data were collected through observation, interviews, and documentation. The data analysis methods included data reduction, data presentation, and conclusion. The instrument in this study was the researcher himself, who conducts interviews with principals and teachers of MTs Darul Huda Mataraman. The researchers also analyzed secondary data such as by viewing documents and files such as those relating to history, vision, school mission, history list of incumbent principals, educators, the background of the school's establishment, the number of students, facilities, and infrastructure owned by the school and graduates' achievements at Mts Darul Huda Mataraman in the last three years.

\section{RESULTS AND DISCUSSION}

In facing the challenges of Covid-19, namely in an all-online learning process that requires media and learning tools that can support the online learning process, researchers received information that at MTs, Darul Huda Mataraman has implemented an online learning process. for one year. Because MTs Darul Huda Mataraman is located in a sub-district, some students have difficulty following this online learning process. The data package assistance that the government has provided for the online learning process has been provided by the school to all students so that it can be facilitated not to spend money to buy a data package to take part in this online learning.

In this online learning process, one of the teachers said in the interview process conducted by the researcher that $40 \%$ of the learning process uses media such as zoom and google meet, and $60 \%$ of the learning process is by giving assignments. Still, before being given assignments, the teacher has explained the learning material by sending a video presentation of the material. And MTs Darul Huda Mataraman also requires students to attend school once a week because the aim is to stay in touch with students, pray together in the face of this covid-19 event, and provide opportunities for them to ask related questions if they still don't understand the material.

Improving the quality of education in dealing with the challenges of COVID-19 at MTs Darul Huda Mataraman can be further enhanced by various kinds of learning processes, not only by giving assignments or by watching learning materials given by educators students in the form of videos. Teachers gave the students different directions for doing tasks with various creations, such as making teaching materials that can be decorated with colorful cardboard then being photographed and sent as assignments. Teachers used multiple strategies and creativity to provide a learning process that can attract students' interest with various strategies and methods that can make the learning process more enthusiastic.

The facilities and infrastructure at MTs Darul Huda were still lacking. For example, the libraries were not well maintained, and the computers were not working well, thus causing students to become less interested in reading books at MTs Darul Huda library. Therefore, the library rearrangement and repair of facilities and infrastructure should be conducted to support the students' learning.

Achievements in the educational field need to be further improved to provide many achievements in the academic field so that they can improve the quality of education and increase the potential of MTs by participating in competitions held and showing the quality of schools. In terms of achievement in the nonacademic field, it looks better than achievement in the academic field, so it is necessary to increase the achievement of MTs Darul Huda in achieving academic achievements such as taking Arabic lessons. Olympic competitions require preparation and support for 
students who will participate in the competition at the agreed time so that preparations made with sufficient time will produce maximum achievements

In developing IT at MTs Darul Huda Mataraman the researcher conveyed the need to increase literacy in the IT world, especially for educators where researchers got results from interviews that only a few educators/teachers used online media as a learning process as using zoom and google meet. With this Covid-19, educators are required to be able to use social media in order to access the online learning process with students. MTs Darul Huda Mataraman needs to improve skills for educators, perhaps by bringing in people who have a good understanding of usage. Online-based media for the learning process. Learning so that little by little will turn into a better direction in carrying out the online learning process at MTs Darul Huda Mataraman.

In general, teachers and students in Indonesia experience excessive anxiety, pressure, and fear that will slow down the educational process. Teachers experience high levels of stress because activities must now be limited and diverted to distance learning [8]. Information and communication technology (ICT) is a powerful force for economic, social, political, and educational reforms that are taking place around the world, including in developing countries [9].

The COVID-19 pandemic has had a significant impact on social, economic, and cultural life globally. The educational dimension has also been affected in regularly functioning schools, with temporary closures of educational institutions and barriers from face-to-face classes [10]. The current global health crisis of COVID19 is unprecedented. This is considered one of the turning points in history where it shuffled social and economic norms as we know them and sparked a new human era. Governments, communities, and organizations are in crisis mode and seeking guidance from their leaders [11].

The development of the digital revolution requires teachers, and teachers will be able to adapt to provide digital learning resources for students. Therefore, it is natural that attention should be paid to teachers and prospective professional competencies in using digital literacy in instructional commitments. More clearly, future teachers see that sooner or later, they will become school teachers in the digital age. In addition, the use of digital literacy in classroom learning is a business need. Teachers' digital is an important part of their teaching abilities in accordance with the challenges that arise from the conditions of their students in the field [12]. The progress of the times that we feel now and technological advances impact students where outside the school environment they are more focused on cellphones, laptops, or computers so that textbooks are their current concern. Their various applications can give students access to learning and bring education in technological advancements.

However, the definition of quality education continues to develop contextually. There is no single definition, criteria, curriculum, or list of topics covering quality education. Quality education is a dynamic concept that changes and develops over time. It is modified according to social, economic, and environmental contexts [13]. Schools with higher quality tend to produce better graduates [14]. In the context of the Indonesian nation, improving the quality of education is a development goal in national education and is an inseparable part of efforts to improve the quality of the Indonesian nation as a whole [15]. Quality education must be seen from the various input components, curriculum, human resources, and the creation of a conducive learning atmosphere. School management which is under the authority of the principal, and class management under the teacher's authority, has the function of synchronizing various inputs or synergizing all components in the teaching and learning process and realizing quality education are the implementation of a quality process [16].

\section{CONCLUSION}

Based on the results of observations, interviews, and documents from schools, it can be concluded that the Covid-19 outbreak is challenging for MTs Darul Huda Mataraman, particularly in implementing online learning. The challenges related to facilities and infrastructure. The MTs have provided the students an internet quota and arranged once-a-week offline schooling to assist the student with the learning. However, the facilities and infrastructure at Mts Darul Huda Mataraman are still inadequate and need significant improvements. This is particularly important considering that MTs Darul Huda Mataraman is the first school established at the sub-district level based on Islamic religious knowledge to provide quality education and services to students and the surrounding community.

\section{ACKNOWLEDGMENTS}

The author would like to thank the Principal of MTs Darul Huda Mataraman, educators at MTs Darul Huda Mataraman, Administrative and Business Staff at MTs Darul Huda Mataraman, who have allowed researchers to explore information and data related to the research topic. The researcher would like to thank the Yogyakarta State University campus for the research support.

\section{REFERENCES}

[1] M. Mardhatillah, M. Musdiani, and K. Khausar, "Analysis the Role of Headmaster in Applying 
Quality of Education in Primary School Kabupaten, Aceh Barat," Budapest Int. Res. Critics Linguist. Educ. J., vol. 2, no. 3, 2019, pp. 19-27. DOI: $10.33258 /$ birle.v2i3.349.

[2] K. S. Louis and J. Murphy, "Trust, caring and organizational learning: the leader's role," J. Educ. Adm., vol. 55, no. 1, 2017, pp. 103-126. DOI: 10.1108/JEA-07-2016-0077.

[3] N. Aniskina and E. Terekhova, "Innovative methods for quality management in educational organizations," Int. J. Qual. Reliab. Manag., vol. 36, no. 2, 2019, pp. 217-231. DOI: 10.1108/IJQRM-12-2016-0235.

[4] Mailizar, A. Almanthari, S. Maulina, and S. Bruce, "Secondary school mathematics teachers' views on e-learning implementation barriers during the COVID-19 pandemic: The case of Indonesia," Eurasia J. Math. Sci. Technol. Educ., vol. 16, no. 7, 2020, DOI: 10.29333/EJMSTE/8240.

[5] M. Adnan, "Online learning amid the COVID-19 pandemic: Students perspectives," J. Pedagog. Sociol. Psychol., vol. 1, no. 2, 2020, pp. 45-51. DOI: $10.33902 /$ jpsp.2020261309.

[6] U. Kaden, "Covid-19 school closure-related changes to the professional life of a k-12 teacher," Educ. Sci., vol. 10, no. 6, 2020, pp. 1-13. DOI: 10.3390/educsci10060165.

[7] N. W. A. Majid and S. Fuada, "E-Learning for society: A great potential to implement education for all (EFA) movement in Indonesia," Int. J. Interact. Mob. Technol., vol. 14, no. 2, 2020, pp. 250-258. DOI: 10.3991/ijim.v14i02.11363.

[8] A. Supriyanto, S. Hartini, W. N. Irdasari, A. Miftahul, S. Oktapiana, and S. D. Mumpuni, "Teacher professional quality: Counselling services with technology in Pandemic Covid-19," Couns. J. Bimbing. dan Konseling, vol. 10, no. 2, 2020, p. $176 . \quad$ DOI: 10.25273/counsellia.v10i2.7768.

[9] A. Habibi, R. A. Razak, F. D. Yusop, A. Mukminin, and L. N. Yaqin, "Factors affecting ict integration during teaching practices: A multiple case study of three indonesian universities," Qual. Rep., vol. 25, no. 5, 2020, pp. 1127-1144. DOI: $10.46743 / 2160-3715 / 2020.4150$.

[10] M. J. Sá and S. Serpa, "The covid-19 pandemic as an opportunity to foster the sustainable development of teaching in higher education," Sustain., vol. 12, no. 20, 2020, pp. 1-16. DOI: $10.3390 /$ su12208525.

[11] K. M. Dirani et al., "Leadership competencies and the essential role of human resource development in times of crisis: a response to Covid-19 pandemic," Hum. Resour. Dev. Int., vol. 00, no. 00, 2020, pp. 380-394. DOI:

\subsection{0/13678868.2020.1780078}

[12] E. F. Rusydiyah, E. Purwati, and A. Prabowo, "How to use digital literacy as a learning resource for teacher candidates in Indonesia," Cakrawala Pendidik., vol. 39, no. 2, 2020, pp. 305-318. DOI: 10.21831/cp.v39i2.30551.

[13] R. Laurie, Y. Nonoyama-Tarumi, R. Mckeown, and C. Hopkins, "Contributions of Education for Sustainable Development (ESD) to Quality Education: A Synthesis of Research," J. Educ. Sustain. Dev., vol. 10, no. 2, 2016, pp. 226-242. DOI: $10.1177 / 0973408216661442$.

[14] R. Boleslavsky and C. Cotton, "Grading standards and education quality," Am. Econ. J. Microeconomics, vol. 7, no. 2, 2015, pp. 248-279. DOI: $10.1257 / \mathrm{mic} .20130080$.

[15] Feiby Ismail, "E. Mulyasa, Menjadi Kepala Sekolah Profesional dalam Menyukseskan MBS dan KBK (Bandung: PT. Remaja Rosdakarya, 2005), him. 31 1,’2017, pp. 1-2.

[16] I. I. F. Syukri, S. S. Rizal, and M. D. Al Hamdani, "Pengaruh Kegiatan Keagamaan terhadap Kualitas Pendidikan," J. Penelit. Pendidik. Islam, vol. 7, no. 1, 2019, p. 17. DOI: $10.36667 /$ jppi.v7i1.358. 